\title{
Glass Curtains and Storied Landscapes: \\ The Fur Trade, National Boundaries, and Historians
}

\section{Bethel Saler and Carolyn Podruchny}

It may be unusual to find an essay about the historiography of the fur trade in a collection that considers the history of national borders. At first glace, national borders should play a very small part in the history of the fur trade because most of it occurred before the border dividing Canada from the United States was firmly drawn. Yet, this essay explores how historians' national consciousness informed their rendering of North American fur trade history. Rather than studying the fur trade on its own geographic terms, many scholars have cast the fur trade as the birthing place of one transcontinental nation and a regional footnote of another. Such national distinctions underscore how historians contribute to the formation of borders as ideas and spaces that reinforce the authority of the nation-state. In representing borders usually implicitly in their narratives, fur trade historians, however, also take part in a more ambivalent discourse about the construction of national borders that similarly captivated the writers of tourist literature explored by Catherine Cocks and the makers of border films analyzed by Dominique Brégent-Heald--essays that precede this article. Collectively, the North American fur trade histories written by Canadian and American scholars forms an unresolved and open-ended literature that while often reaffirming national borders also reveals a subject in which national borders constitute only one of many overlapping territorial spaces, spaces that factored into the contingent understandings and political power of national 
divides. The fur trade as subject, like tourist literature and border films, offers a site to unravel the historical and distinct cultural meanings articulated by people when they creatively narrated border spaces.

The fur trade comprised a trade of fur pelts, primarily beaver, produced by Aboriginal people, and material goods produced in Europe. The trade began informally in the first half of the sixteenth century by western Europeans and it became the major commerce in the colony of New France from the early seventeenth century onwards. The British began to trade for furs in North America when the crown chartered the Hudson's Bay Company in 1670. After the British conquest of New France in 1763, the Montrealbased trade continued in small partnerships that eventually merged into the North West Company in 1779. The Jay Treaty of 1794 secured the lands south of the Great Lakes for the United States, and in 1818 the forty-ninth parallel was established as the northern boundary of the Louisiana Purchase, separating the United States from what would become Canada up to the Rocky Mountains. Although all were allowed to trade on either side of this border, providing they paid taxes, American traders attempted to drive away Canadian traders from the areas immediately south of the line. In 1808 John Jacob Astor established the American Fur Company and later other subsidiary companies. An 1817 Act of Congress excluded foreign traders from U. S. territory, after which the American Fur Company dominated the U. S. trade until its demise in 1850. In 1821, the North West Company merged with the Hudson's Bay Company, and in 1870 the company transferred much of its land to the newly created Canadian nation and continued their operations in the far north until World War II. 
Though Britain and the United States set national boundaries cutting through the Great Lakes region in 1785, Native, European and Euroamerican residents continued to adhere to the diverse and long-standing geographies of the North American fur trade. American politicians sought this boundary as a means of removing the British military from their posts on the American side of the border (a process not fully realized until 1796), and of forcing British inhabitants living on now American soil to assume U.S. national allegiances and identities. By setting this new Canadian-American boundary, the U. S. Congress put into motion centripetal forces intrinsic to the formation of any nation-state: they promoted popular and territorial cohesion, insisted on loyalty from its new residents, and encouraged people to look inwards, to invest themselves and their communities with a national consciousness. Yet other centrifugal forces influenced local inhabitants' territorial allegiances, distracting them with different ideas about how to view the land on which they lived, worked and traveled. In the case of the fur trade, it produced its own territoriality of trading posts and Native hunting camps and of commercial centers in Montreal and London. Moreover, aboriginal conceptions of territoriality continued to shape localized fur trade landscapes, ideas of territoriality that conflicted with the new northern U. S.- British North America boundary line and the land tenure systems of the new European settler communities.

The first part of this essay considers how much of United States and Canadian fur trade historiography has implied the inevitability and stability of national borders and bordered states by invoking national myths of state-making. Because American and Canadian national origin stories are discrete, the two national historiographies of the fur trade situate it in very different ways within their national narratives. At the same time, 
not all works fall into this categorization. Some fur trade histories have revealed alternative historical and geographic imaginings that challenge the universality and exclusivity of nation-state-centered histories. ${ }^{\text {ii }}$ This fur trade historiography makes clear that one group's historical geography or "storied landscapes" as Colin Calloway has termed it, cannot serve to explain another peoples' experiences in and understanding of the same space. ${ }^{\text {iii }}$

Following this theme, the second part of this essay argues that the history of the North American fur trade at different points in time and place and for different groups of people encompassed alternative definitions of territory and community to those of the nation-state. Because of its central narrative of cultural encounter, the fur trade brought together a diversity of people who imagined the geographic worlds they inhabited in distinct ways. These insights are important to the study of borderlands because they expose the fractured and contingent meanings of national borders-- they did not exist in all circumstances for all people. Further, the sweep of time and scale of the North American fur trade, stretching from the sixteenth through the twentieth centuries and representing overlapping local, regional, national and international enterprises, reveals the transience and vulnerability of national and imperial state borders to the dictates and interpretations of other political spaces.

\section{Of National Historiographies and Glass Curtains}

Although the United States and Canadian border did not interfere in the various operations of the North American fur trade until late in the game, nationalist attitudes are particularly pronounced in much of its written history and many fur trade scholars in each 
country have shuttered their view of stories from the other side of their national divides. The disparate interpretations of the fur trade in Canada and the United States serve the different national narratives. The fur trade scholarship in the United States is a less substantial body of literature than that produced in English Canada. In contrast to the central place that Canadian historians have given the fur trade in their national development, American scholars have not considered the trade a particularly important factor in the rise of their nation. Whether explicitly or not, historians have relegated the fur trade to a transient and regional phenomenon. Racially mixed and multinational trading populations offer colorful and exceptional stories to the mutually informing main narratives of American agrarian settlement and urban development spreading across the continent.

Americans' privileging of agrarian settlement in their nationalist origin story expressed the particular late eighteenth-century context of their forays into nation-state formation. Unlike Canada, the United States formed its national identity in rebellion against the British Empire. Their union of settler states dedicated to still protean notions of modern republican governance represented a resounding ideological break from their former colonial history. No longer living in an imperial space defined by subjection to a monarch, Anglo-Americans perceived themselves as members of a collectively "owned" territorially defined nation. Lockean republican theory posited that the most basic job of the state was to protect property; and Americans initially assumed property ownership as a fundamental criterion for political membership and of settled permanent life.

Landed property owners such as farmers manifested the idea of a property-based territoriality. Farmers represented the interior of the nation, the settled parts or those in 
the process of being cultivated. Moreover, though revolutionaries disputed a future of manufacturing versus agricultural-based economies, a romantic faith in the rejuvenating powers of an agrarian economy and farmers as the model citizens became a core part of national mythology by the early nineteenth century. ${ }^{\text {iv }}$ In all these ways, (legal) agrarian settlement realized the republican territorially based identity of the American nationstate. The fur trade, in contrast, held a decidedly colonial legacy: it took place in lands inhabited by Aboriginal peoples, it was both mobile and transitory, and it was a reminder of the messier reality of competing and confusing claims of Indian and French colonial possession undermining the state's idealized assertions of sovereignty.

Popular history representations of the fur trade as a colorful and fleeting antecedent to permanent, that is real American settlement can find no better founding father than the early nineteenth-century author, Washington Irving. After securing acclaim in Europe during a long sojourn, Irving returned to his native land and turned his hand to chronicling the romance of the American west. He wrote three books in quick succession in the mid-1830s. First he recounted his own travels across U.S. Indian Territory (present day Oklahoma) in A Tour of the Prairies (1835). Then, over the next two years, Irving wrote two books about fur trading and exploration in the Pacific Northwest: Astoria (1836) about fur magnate John Jacob Astor's failed attempt in 181012 to capture a part of the Columbia river trade and The Adventures of Captain Bonneville (1837), an account of the thrilling explorations of Captain Bonneville whose "rambling kind of enterprise, had strangely engrafted the trapper and hunter upon the soldier."v Astor, the financier of both his own company's and Bonneville's Pacific Northwest expeditions, supplied Irving with his entire archive of the Astoria venture. 
Since most of this material consisted of business papers, Irving looked for social insights and comparable experiences in the journals of other explorers in the same region and in the case of the second book, he relied on the notes and maps of Captain Bonneville. ${ }^{\text {vi }}$ Out of this careful, evidentiary research, Irving hoped to narrate the "the stories of these Sinbads of the wilderness," and to capture "[their] perilous adventures and hair-breadth escapes among the Indians." ${ }^{\text {vii }}$ He declared that the importance of their adventures lay in the historic role performed by fur traders generally as "pioneers and precursors of civilization." First French, then British, and finally American traders laid open "the hidden secrets of the wilderness leading the way to remote regions of beauty and fertility that might have remained unexplored for ages, and beckoning after them the slow and pausing steps of agriculture and civilization." viii

Almost fifty years after Irving's fur trade writings, historian Frederick Jackson Turner published The Character and Influence of the Indian Trade in Wisconsin (1891), which claimed a professional academic imprimatur to speak for the nation including the narrative of the fur trade as a necessary savagery in the evolution toward agrarian civilization. Turner viewed the trader as "the pathfinder for civilization, ${ }^{\text {,ix }}$ but not $o f$ it. The Character and Influence of the Indian Trade in Wisconsin, Turner's first published monograph and his dissertation, foreshadowed his famous "frontier thesis" by situating this localized exchange economy as an early stage in the ineluctable progression of American settlement in Wisconsin toward soil cultivation and finally the manufacturingbased economy of his present day. Euroamerican property ownership and agrarian settlement were the signifiers of permanent society, in other words, "civilization." Fur traders and trappers, on the other hand, with their mobile hunting life, dependence on 
finite animal supplies, and their infamous habits of adopting Native customs and relationships, embodied an oppositional Euroamerican "barbarism."

Much of American fur trade historiography over the twentieth century has followed Turner's lead of constructing fur traders and trappers as "precursors" in an American advance westward that inevitably eclipsed their mobile exchange economies. A sense of doom hangs over this interpretation of the American fur trade as well as a centralizing pull toward an established coherent United States. American fur trade historians falling under this "spell of inevitability," run into the problem of claiming national importance for a subject both transient and counter to the central developments of agriculture and manufacturing. ${ }^{x i}$

The first line of defense has been for scholars to extol traders' importance as pathfinders and explorers. Trappers living west of the Mississippi River in the 1830s and 1840s, according to Sydney Greenbie's Furs to Furrows (1939), were "always some 500 miles ahead of the army, the missionaries, and the land-hungry pioneers, showing them the way ... . " ${ }^{\text {xii }}$ Robert G. Cleland in 1950 insisted on a "reckless breed" of trapper and trader in the American Southwest, that "[t]he feet of the nation walked his halfobliterated trails, the course of empire followed his solitary pathways to the western seas." ${ }^{\text {xiii }}$ In the $1960 \mathrm{~s}$, Walter O'Meara maintained that fur traders and trappers, not "the people of the covered wagons or the bearded forty-niners ... [who] led the westward march of the frontier." These men "were the true spearheads of Manifest Destiny." xiv Richard Dillon highlighted in 1975 that the early California trade provided a path later followed by the gold rush and railroads and in a 1997 monograph, Robert Utley called fur 
traders "the point men, the advance guard, of a nation unfolding westward, geographically and politically." ${ }^{\mathrm{xv}}$

A few studies of the American fur trade though have made much bolder claims to national significance. Such scholarship has argued that, at different points in time, trading matters and national or imperial concerns were inseparable. The fate of the fur trade and the nation-state or empire, in other words, was one and the same. David Lavender's Fist in the Wilderness (1964), for example, depicts John Jacob Astor's attempts to monopolize the fur trade in the American portions of the Great Lakes as a critical part of a national effort to free the United States finally from the yoke of British economic dependence. John C. Phillips and J. W. Smurr's masterful two-volume The Fur Trade (1961) presents nearly two centuries of the North American fur trade as a story of imperial competition among European and American nations. Though endowing the fur trade with greater weight than most histories, the imperial or republican nation-state still holds center stage as the master subject. ${ }^{\text {xvi }}$ This view imposes a progressive narrative of nation-state formation on a subject not wholly within or subsumed by the national political community. While policies of imperial and national governments affected the fur trade, other distinct dynamics such as international markets, local agendas, and Indian politics also determined its course. By the same token, the fur trade only inconsistently and in combination with other international and local factors influenced the shape of national and imperial politics.

By far the most common fate of the fur trade within American historiography has been its subordination as a topic of regional, rather than national importance. The majority of the American fur trade scholarship has focused on parts of the Great 
Lakes/Midwest region (including Missouri), the Southern Rockies, the Southwest and the Pacific Northwest. This fact in and of itself does not presume regionalism however. Graduate programs in American history, professional organizations, journal editorial boards, academic publishers, and many fur trade historians themselves have reinforced the idea of the regional particularity of the American fur trade. That is, regions are constructed categories, the work of scholars as well as many other groups and individuals-- including boosters, politicians, and local residents-- wishing for various reasons to cohere and distinguish a particular area. Those areas also exist in a relational role to the master subject of the nation-state. In the spaces of the fur trade, however, European, Euroamerican, and mixed-race traders and their Native exchange partners more often operated in geographic worlds defined by labor, kin, culture, natural environment, and company affiliations than from a self-conscious notion of region or nation.

Ironically much of fur trade scholarship pigeonholed as regionally specific challenges the coherence of the nation-state and its centrality in trading narratives. Both the Pacific Northwest and the Southwest regions, for example, long were imperial battlegrounds among a host of European powers and the United States well after the latter had established its independence. American imperial conflicts with other nations lie at the center of accounts of the Southwest fur trade such as Gloria Griffen Cline's Exploring the Great Basin (1963) and David Weber's Taos Traders (1969). And similarly, imperial competition and the overlapping sovereign claims of numerous nations frame Pacific Northwest fur trade scholarship such as James Ronda's Astoria and Empire (1990) and James Gibson's Otter Skins, Boston Ships and China Goods (1992) to name just two. In 
this way, these "regional" fur trade literatures raise numerous points of national significance: the transitory nature of empires and their boundaries; the United States' domestic imperial history; and the diverse ways that European, Euroamerican and Native inhabitants resisted, ignored or gave shape to territorial borders at the local level. In marked contrast to American historiography, English Canadian national histories depict the fur trade as a cornerstone in the development of the Canadian nationstate. $^{\text {xvii }}$ In one sense, this contrast originates in the different patterns of British colonization in these two parts of North America, differences that speak also of geographic distinctions. The lower thirteen British colonies in North America attracted a vastly larger European immigration than Canada and built diverse economies out of the environments endemic to particular Atlantic colonies. The geographic and climatic shift northward to Canada drops the total arable land from the small number of $19 \%$ of the continental United States to the miniscule amount of 5\% of the landmass of Canada. This fact combined with the smaller settler population meant that agricultural settlement in Canada occurred at a slower pace and over more limited terrain than in the United States. At the same time, the small percentages of arable land in both countries correspond with the importance of extractive industries such as lumber, mining, (fur/hide) hunting, and fishing in the growth of both national economies. Particularly in the beginnings of European mercantile empires in North America, new colonies were expected to supply ready markets for finished goods and staple or raw products to their respective European centers of empire. Thus, in the lower thirteen British colonies of North America, fur trading as well as other extractive industries mixed collectively with animal husbandry, 
and staple and diversified farming in distinctive patterns that yielded different regional economies.

The powerful, republican associations of national independence with domestic manufacturing and agriculture, however, have tied those two forms of economy to the emergence of the American nation-state in ways not true of the fur trade. In contrast, English Canadian national histories do not emphasize a rupture with their colonial past, but on the contrary, envision their nation as organically developing within the French and British empires in North America. This tie between colony and nation-state in Canadian histories meant that chroniclers depicted the fur trade as introducing civilization into northern wilderness, not as a precursor thereof. Alexander Ross, for instance, an early nineteenth-century Scottish migrant, lifelong fur trader and a founding citizen of the multi-racial Red River colony (in present-day Winnipeg, Manitoba) wrote about his trading adventures and settled life at Red River as forays of progress in a wilderness. Ross's book The Red River Settlement (1856) described that colony as an island of civility in vast oceans of savage forest and prairie, and he implied that trading furs and establishing a line of posts along canoe routes were acts of civilization. ${ }^{\text {xiii }}$ Subsequent narrators of western Canada reinforced Ross's view of the fur trade as foundational to this early national nucleus, such as the classic works-- W. L. Morton's Manitoba: A History (1957) and George F. G. Stanley's The Birth of Western Canada (1961). ${ }^{\text {xix }}$

Paralleling the influence of Frederick Jackson Turner on American fur trade historiography, the scholarship of Harold Adams Innis critically shaped Canadian fur trade historiography and the concomitant central place of the fur trade in the formation of the Canadian nation. In The Fur Trade in Canada (1930), Innis asserted that "the present 
Dominion emerged not in spite of geography but because of it. The significance of the fur trade consisted in its determination of the geographic framework." ${ }^{\text {xx }}$ In other words, the main posts of the Hudson's Bay Company and North West Company became the geographic framework for the western and northern part of the Canadian nation. Innis framed his study in nationalist terms by portraying furs as one of the staple economies that shaped the country's political borders. In the east, the main staple exploited by merchants was cod, and the geographic extent of the cod fisheries served as the geographic imprint for the Maritime provinces. The exploitation of wheat did the same for central and western Canada. Innis argued that the successive economies that were built on various staples provided the chronological framework for the emergence of the Canadian nation. The fur trade and the nascent Dominion of Canada, Innis argued, spread across the continent long before the Americans. ${ }^{x x i}$

Innis's work was underscored by one of the pillars of Canadian history -- Donald Creighton, whose 1937 Commercial Empire of the Saint Lawrence proposed that Canadian history could be best understood as an expansion westwards of the fur trade, which built the architecture for the later east-west trading of other staples. Creighton argued that Canadian economic and national development derived from the gradual exploitation of key staple products--fur, timber and wheat--by colonial merchants in the major metropolitan centers along the St. Lawrence River system. The staple products were sold to major European cities, creating a transatlantic and transcontinental economy that undermined the continentalism implicit in Turner's frontier thesis. In Canada: A Story of Challenge (1953), J. M. S. Careless extended the staples and Laurentian theses by exploring the consequences of metropolitan areas exploiting regional hinterlands. 
Although the exploitation of staples occurred within regions, the flow of harvested products, laborers, and goods between the resource-rich regional hinterlands and the heartland of mercantile trade, manufacturing, and political governance (which eventually became the Quebec City- Windsor corridor of central Canada) made the staples theory a story of nation-building.

Up to the 1970s, scholars followed Innis's interpretation of the fur trade as a central resource industry and an important first step in the building of the Canadian nation. This robust historiography has been well studied. As early as 1973, L. G. Thomas published a comprehensive literature review of what he termed "the fur trade era," observing that most English-Canadian work only covered the period from 1763 to 1870 and focused exclusively on the west and north of Canada. ${ }^{\text {xii }}$ These histories, mainly concerned with business and empire, focused on fur trade companies that located their stories primarily in the early Canadian northwest, that is, the Hudson's Bay Company and North West Company. The volume devoted to the fur trade in the Canadian Centenary Series, E. E. Rich's The Fur Trade and the Northwest to 1857 (1967), is divided equally among the histories of the North West Company, the Hudson's Bay Company, and the reconstituted company after these two merged in 1821 . The biographies of fur trade explorers, another popular topic in this classic historiography, supported the nationalist framework by celebrating great men who overcame severe tests of their strength and fortitude to bring commerce and civilization to the Indians, and map the wilderness for the British and later Canadian empire. Marjorie Wilkins Campell's The Nor'westers: The Fight for the Fur Trade (1954), The North West Company (1957), and McGillivray, Lord of the Northwest (1962) are perfect exemplars. 
The 1970s witnessed a broad shift in fur trade historiography that paralleled developments in other historical fields for social history "from the ground up." Scholars became interested in the everyday lives of ordinary people and turned their attention away from great men and top-down perspectives on nation building to community studies focused on women, families, workers, and Aboriginal people. Their work constituted a revolutionary change in the questions scholars asked about the trade and in the sources they used. It also brought out new dimensions and perspectives on the trade, suggesting the diverse workforces and social geographies contributing to this broad subject. In 1980, for instance, two groundbreaking studies appeared that showed the centrality of family, marriage and women's roles within the formation of trading economies in Canada. Sylvia Van Kirk's 'Many Tender Ties' (1980) highlighted that key roles of Native and métis women in trade relationships as wives, cultural brokers and traders. At the same time, Jennifer S. H. Brown's Strangers in Blood traced the new family structures and complicated racial politics emerging from Hudson's Bay Company employees' marriages with Native peoples. Others have explored the labor history of the fur trade in comparative studies of the American Fur Company and the Hudson's Bay Company, looking at servant resistance to master authority, and examining the wide cultural variety of laborers, including French Canadians, Orcadians, Iroquois, métis and Algonquians. ${ }^{\text {xiii }}$

In tandem with these new social histories, scholars started to take seriously Native peoples' particular perspectives of the fur trade. Combining research techniques from history and anthropology, a renewed ethnohistorical literature invigorated fur trade investigations by transforming Aboriginal people from mono-dimensional, passive 
characters to full-scale trading partners with their own particular histories. Such Nativecentered histories revealed the cultural beliefs and customs including ideas of territoriality influencing Indian peoples' participation in the trade. Arthur Ray's 1974 Indians in the Fur Trade, which led the way in Canada, pursued the question of why Aboriginal people entered the fur trade and what they gained from it. His later work with Donald Freeman in 'Give Us Good Measure' (1978), and books by Robin Fisher, Toby Morantz, and Paul Thistle, to name a few, have generally shown that Native peoples were neither pawns in the trade, nor dependent on European trade goods, nor were their economic and social systems rapidly and radically transformed by contact with Europeans. ${ }^{\text {xxiv }}$ Instead these scholars showed that Europeans accommodated to Aboriginal trading systems and concomitantly, their notions of space.

Similar American ethnohistorical studies reaped textured new histories of Indian peoples and also new attention to the fur trade particularly within colonial American history. ${ }^{\mathrm{xxv}}$ Innovative "colonial-era" scholarship over the last twenty-five years has brought attention to distinctive Aboriginal epistemologies about land and trading, such as Calvin Martin's Keepers of the Game (1979), William Cronon's Changes in the Land (1983), Richard White's Roots of Dependency (1983) and later, The Middle Ground (1991), Bruce White's many articles, Kathryn E. Holland Braunds's Deerskins and Duffels (1996) and Colin Calloway's One Vast Winter Count (2003).

The rise of ethnohistorical explorations of the fur trade in Canada and the United States also garnered new notice to the children of European traders and Native women, the métis or mixed-race peoples. This group first received extensive attention in 1945 with Marcel Giraud's Les Métis canadien, which considered them as a step between 
savagery and civilization. After doctoral dissertations by Fritz Pannekoek and John Foster, both completed in 1973, studies of multi-ethnic families gained momentum. Jacqueline Peterson's 1980 dissertation “The People in Between," which examined the ethnogenesis of the métis in the Great Lakes region, asked when and how ethnically distinct métis communities emerged. Peterson's and Brown's edited collection The New Peoples: Being and Becoming Métis (1985) quickly carved out métis studies as a stable field of inquiry and remains the most widely cited work on métis history to date, despite the recent explosion in the field. ${ }^{\mathrm{xxvi}}$

In the United States, the same regionally based métis studies abound, revealing the complexity of identities, customs and social spaces alterior to and existing simultaneous with dominant national, racial, and cultural definitions. In her study of the lower Missouri River, Tanis Thorne chose the metaphor "Many Hands" for the title of her study of "the interrelationships of French Creoles and Central Siouan tribes" and the localized fur trade they cultivated. Such a metaphor, Thorne explains, refers to "the various human relationships that cross and often transcend cultural, ethnic or national boundaries."xxvii Susan Sleeper-Smith and Lucy Eldersveld Murphy have also explored the strategies with which Euroamerican and Indian fur trade communities in parts of the Midwest retained local distinctiveness and resisted social disintegration in the face of an imposition of dominant Anglo-American customs, and racial and spatial identities. In Indian Women and French Men (2001), for example, Sleeper-Smith charts the critical power of femaledominated, Catholic Indian (and eventually also métis) kin networks in southwest Michigan and northwest Indiana to minimize incursions of American market forces and to ward off removal from their homelands. Similarly in A Gathering of Rivers (2000) 
Lucy Eldersveld Murphy demonstrates the ways that both Wisconsin Indian and FrenchIndian trading peoples diversified their production to adapt to a dominant American market economy while also shaping their local portion of that national economy. Their expansion of their maple sugar yield, their fabrication of Indian keepsakes, beadwork and weaving for the tourist trade all marked their region with their separate (counter-national) heritage and selfhood. In contrast to these Midwestern stories of persistence of alternative identities and spatial definition, John C. Jackson's investigation of Pacific Northwest métis in the eighteenth and nineteenth centuries in The Children of the Fur Trade (1995) focuses on the ephemerality of a people who disappeared from record in the face of more rigidly defined borders and national identities.

For scholars of borderlands, these studies of racially-mixed and Indian fur trading communities intimate alternative social geographies operating simultaneously with those of the nation-state. The full implications of these border-challenging facets, however, largely have gone unrealized until recently. While United States and Canadian historians have provided a wealth of suggestive community and regional studies of Native and métis or mixed-race peoples in the fur trade, national borders still implicitly frame depictions of these communities. The border between Canada and the United States seems to act like a glass curtain. Scholars of the fur trade do not pay any attention to it, yet they seem to be unable to pass through it.

Although the focus on the history of Aboriginal peoples often fosters a centrifugal model of geographic imaginings, very few studies span the Canadian and American border, and the divide between Canada and the United States looms as a divide for subjects and sources. Scholars situated in Canada write about Natives situated in Canada 
and generally confine their scholarly reviews to scholars and topics in Canada. This disturbing tendency shutters fur trade scholars on either side of the border.

In Canada the falling out of fashion of fur trade history has compounded this trend. The best social and cultural history on the fur trade has shifted from university academics to federal employees working at National Historic Sites administered by the Parks Canada Agency, such as at Lower Fort Garry in Manitoba, Rocky Mountain House in Alberta, and Fort Langley in British Columbia. ${ }^{\text {xxiii }}$ The work of these federally employed historians, anthropologists and archaeologists is exceptional, but they are required by their government mandate to reinforce the nationalism of the fur trade scholarship. ${ }^{\text {xix }}$ Thus, they interpret Canadian historical sites for a Canadian national public out of the relevant historical sources and the material culture found at those sites. In other words, historic sites and public commemorations have followed academic developments in emphasizing the agency of Aboriginal people and women and revealing the multivocality of the past, yet it is always presented within the guidelines of Canadian national heritage commemoration.

A few studies in both Canadian and U. S. Aboriginal history deserve special note for highlighting the border challenges raised by the North American fur trade as a subject by focusing specifically on trans-national geographies peculiar to some of these "counter-

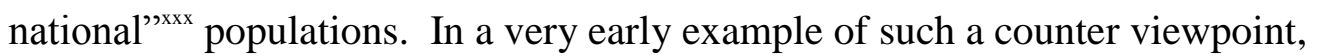
anthropologist Oscar Lewis's notable study The Effects of White Contact Upon Blackfoot Culture assumes the territoriality of the Blackfoots rather than that of United States, and thus he looks equally at the different Canadian and American policies on the Indian trade. In so doing, Lewis emphasized how the Blackfoots lived on both sides of 
the international line, their group identities not exclusively determined by one side or the other.

The most recent examinations of métis have gone to the greatest lengths to dispel the exclusive nationalist framing in fur trade studies. Such awareness is probably tied to the fact that national borders profoundly shape métis political identity given that the Canadian government recognizes the métis as a distinct Aboriginal group and constitutionally protects their (as yet undefined) rights, while the United States government does not. ${ }^{\text {xxi }}$ A surge of community studies, including Diane Payment's “The Free People -Otipemisiwak” (1990), Pannekoek’s A Snug Little Flock (1991), Gerhard En's Homeland to Hinterland (1996), Nicole Ste.-Onge's Saint-Laurent (2004), and Michel Hogue's article in this volume all illustrate the great variety of the métis experience and imply that their findings are not restricted to north of the $49^{\text {th }}$ parallel. Worthy of special note for its transcendence of borders, Heather Devine's The People Who Own Themselves (2004), illustrates the journey of a métis family across nations and generations from seventeenth-century France to an Alberta reserve in the $20^{\text {th }}$ century. Tracing her ancestral genealogy, Devine chronicles 250 years of border crossing by the Desjarlais family. By the same token, this family journey in time and space also illustrates the historicity of borders as they disappear and morph into new political boundaries and internal borders within the nation. The Desjarlais traveled from early modern France to the Saint-Lawrence valley under the French regime, colonial Louisiana, St. Louis, the Missouri region, the American Southwest, the Red River settlement and finally reserved land of the central Albertan plains. 
Despite recent work in ethnohistory and indigenous studies, much of the scholarship on the fur trade has been indirectly but profoundly shaped by national borders. Scholars based in Canada have featured the fur trade as the conception of the Canadian dominion, rooted in a mercantilist economy of resource extraction on the edges of empire, while scholars based in the United States have dismissed the fur trade as a small stumble on the path of the inexorable tsunami of republican civilization. The reduction of the multi-scaled topic of the fur trade to solely national narratives reflects the central focus on the nation-state within the production of history. But, as we shall see in the following section, scholars who have been particularly sensitive to the geographic organization of the fur trade have provided models for overcoming this form of nationalism. The fur trade as a historical subject provides an excellent model for thinking in more capacious and contingent terms about the many layers and scales of historical borders within which people interact, including but not exclusive to national borders.

\section{Storied Landscapes}

Nature, culture, and time all colluded in the formation of particular historical fur trade landscapes. On the most primary level environmental conditions gave shape to economic and social spaces dedicated to the hunting and preparation of wild animal skins and furs. Many natural factors collectively contributed to the peculiarities and advantages of different fur trade regions including geomorphology, geology, biology, latitude, altitude, and climate. For example, it is no accident that the beaver fur trade spread along waterways in boreal forests. Not only were rivers and streams important for human travel, but beavers inhabited water courses bordered by forests or areas with ample 
deciduous trees and shrubs. Arthur Ray early on highlighted the importance of the physical characteristics of landscape when exploring Aboriginal and European encounters in Indians in the Fur Trade. In a more recent study, Theodore Binnema's Common and Contested Ground (2001) grants the environment equal and interdependent subject status with the human population in the history of the northwestern plains. ${ }^{\mathrm{xx} x i i}$

Aboriginal notions of territoriality also prefigured and fundamentally shaped fur trade landscapes. Jacqueline Peterson and John Afinson observe that "the fur trade, properly phrased, was an 'Indian trade', and the many new trading landscapes that European-descent and native people formed either originated in or were inflected by older Aboriginal ways of thinking about territory."xxxiii Indian geographies spoke of histories stretching back to ancient periods of North America and of social dynamism propelled by shifting tribal identities, alliances, trade routes, kinship ties, and migrations. Helen Tanner has shown how Native trading networks linked together most of North America well before Europeans arrived on the continent: these "major trade routes of North America" ran along "the waterways, supplemented by footpaths through river valleys, across portages and mountain passes, and along ridges and bluffs of rugged terrain. The largest communication system covered the Mississippi River valley, embracing all the territory between the Appalachian Mountains and the Rockies." ${ }^{x x x i v}$ The crisscrossing networks of Native North American exchanges reflected conceptions of territoriality markedly different from the property-based notions of nationstates. Instead, as Jeanne Kay and Patricia Albers have demonstrated, networks of social relations as well as different sorts of usages premised Native construction of territory. In other words, Indian peoples defined a territory according to both relations among the 
groups who lived there and the social activities carried out within a place. Neutral territory, exclusive and shared hunting grounds and farmland, multi-village regions, sacred ceremonial sites, and ancestral burial grounds all described specific relationships and undertakings - such as alliances, hereditary enemies, labor, kinship, and worship. ${ }^{\mathrm{xxv}}$ Such a conception of territoriality defined by associations produced spaces that were by nature changeable and fluid rather than permanent or fixed. Historian Colin Calloway, for example, explains that counter to the delimiting and permanent or fixed geometry of European mapping, Native maps "did not rely on fixed points within a bounded space, but on patterns of intersecting lines." ${ }^{\text {xxvi }}$ Similarly, Keith Goulet, a Cree from northern Saskatchewan, has explored this conceptual difference between territory as a separate or alienated object versus territory as embodying animate social relationships and activity/use. Goulet points out that European nations and cartographers were unlike the Crees because they created and drew boundaries, borders, and lines on maps that defined their claims, company territories, and empires. In contrast, Crees saw their communities as open-ended, not contained by defined edges. Centralized core settlements were surrounded by villages and hunting camps, which spread out along waterways and into the bush until they touched the resources used by others. ${ }^{\text {xxvii }}$

These tangible matters of social relations and usage that distinguished and defined Native spaces reflected root epistemologies structuring all parts of their cultural and material lives. ${ }^{\text {xxviii }}$ Conceptions of territoriality constitute ideological maps of a society's cultural logic and social identity. Anthropologist Keith Basso, for example, has shown comprehensive ties between territoriality and culture at all levels of Apache consciousness, asserting that "Apache conceptions of land reach deeply into other 
cultural spheres, including conceptions of wisdom, notions of morality, politeness and tact in forms of spoken discourse, and certain conventional ways of imagining and interpreting the Apache tribal past." xxxix $<$ figure 1> Alfred Jacob Miller's painting "The Rendezvous Near Green River, Oregon” gives us a hint of the rich communities and trading patterns Euro-american fur traders would have encountered on the northwest Great Plains.

As European colonials formed trading economies with Aboriginal peoples, they gave shape to new local geographies that while built on prior Aboriginal ideas of territoriality also were distinct from them. Kay and Albers have outlined the main factors that generated a fur trade territoriality in and around Indian lands. First, a profit-driven international market for furs fostered competition over and circulation of trade goods, which led to shifting relations among neighboring tribal groups and between Native peoples and European American traders. Aboriginal communities closest to European colonies, settlements, and trading posts often became middlemen in the trade, especially when local fur-bearing animals became extinct, and re-oriented their economies and alliances to funneling furs and trade goods between the continental interior and European mercantilist centers, as did the Wendats (Hurons) trading with French Canadians and the "Homeguard Cree" (as they came to be known) trading with the Hudson's Bay Company. Second, trading entrepots drew together different trading peoples. Tribes from widely scattered regions came together at European centers, such as Montreal, Michilimackinac, and Grand Portage, to trade with the Europeans and with each other. In the Pacific Northwest a pidgeon language called Chinook Jargon emerged from the medley of languages that met in the trade. Third, ethnically mixed villages reoriented social 
relations and social spaces within Indian country. ${ }^{\times 1}$ In places like Prairie du Chien in Wisconsin, Pembina in North Dakota, and Ile à la Crosse in Saskatchewan, the meeting of diverse peoples and their mixed heritage offspring led to new communities that developed their own alliances, material culture, and even language (such as Michif) distinct from the Aboriginal societies all around them.

Driven by transnational political and economic forces at one end of the spectrum and the vagaries of local politics and European-Indian exchanges at the other, the North American fur trade operated simultaneously on multiple planes. ${ }^{\text {xli }}$ When speaking of fur trade geographies, therefore, one has to distinguish among many spatial scopes that ranged from macro views of global and hemispheric-wide economies to discrete company geographies that contributed to the shape of regional and local trading realms. The broad canvases of global and hemispheric views of the fur trade challenge the too common tendency to see everything in terms of discrete nation-states. A global perspective displays the pattern of international economy and trade, highlighting the spread of mercantile capitalism, and the connections among people separated by vast distances and vastly different cosmologies. This approach has appealed particularly to historians of empire and to those developing an Atlantic World paradigm. ${ }^{\text {xlii }}$ Narrowing from the global to hemispheric perspective renders a fur trade geography encompassing the whole of North America, or the northern Atlantic World, depending on orientation. Viewing how the trade operated across North America or the northern Atlantic as a whole promotes comparative analysis of European exploitation of North American resources, and continental and oceanic trading patterns of both European merchants and Native 
peoples. Although few scholars have taken such a large-scale approach, it is a promising line of inquiry to destablize nationalist and single nation imperial perspectives. ${ }^{\text {xliii }}$

Contracting from the hemispheric, one encounters the most common frame within North American fur trade historiography: the regions within which different fur trade companies operated. Both French and British imperial administrations tried to control the movement and spheres of fur trade ventures in North America, in keeping with the rules of mercantilism. For example, by royal charter of 1670, the Hudson's Bay Company acquired trading rights to all lands draining into Hudson Bay, a vast area that encompassed the homelands of most subarctic peoples, many woodlands peoples, and some plains peoples. With a British monopoly over former French and Dutch fur trade regions by the end of the French and Indian War (1763), however, the Hudson's Bay Company's declared jurisdiction on paper meant little to competing British and AngloAmerican companies. The North West Company, the Hudson's Bay Company's greatest rival before their merger in 1821 , held no charter but rather aggressively sought trading relationships with Aboriginal people and established its posts along major waterways, notably the Great Lakes, Lake Winnipeg, Lake Athabasca, and the St. Lawrence, Saskatchewan, Red, Mississippi, Missouri, Peace and Columbia rivers. New Yorker John Jacob Astor's American Fur Company, as well as his short-lived Pacific Fur Company, attempted to seize the fur trade south of the northern American boundary leading up to and after the War of 1812. The success of companies' geographic ambitions, however, also depended to a large extent on the material factor of available travel routes rather than abstract thoughts about national boundaries; the most common means was the canoe, but as the $19^{\text {th }}$ century progressed, the fur trade relied more and more on York boats, sloops, 
horse trails, and Red River cart trails. The territories of each of the above-mentioned companies shifted with the depletion of fur-bearing animals; they engaged in an ongoing and mobile competition along waterways and Aboriginal trails into new regions still rich in furs. <figure 2> Frederick Arthur Verner's painting "Hudson's Bay Company Canoe" illustrates the smallest scale of trading without even leaving one's canoe.

All of the above fur trade geographies, like a Russian nesting doll, blended into the next toward the decentralized base of action of the trading posts. Post life was enacted locally, both within the post communities and among neighboring posts and Aboriginal communities. ${ }^{\text {xliv }}$ The size of the post and its consequence in the trade determined its impact on the surrounding areas; important posts had higher European populations and a greater impact on the landscape and surrounding societies, while smaller posts left a fainter imprint. European traders attempted to control their small world within fur trade posts. The immediate interests of European colonial offices and American federal agencies governing empire differed substantially from those of fur trade businessmen in Montreal or New York, and from the men contracted to transport furs and goods, work at the posts, and collect furs directly from Aboriginal trappers. Living in Indian homelands, traders formed familiar Europeanized safe spaces for themselves in the face of the demographic dominance and cultural differences of their Native hosts. In Cole Harris's words, they created "islands of relative security" by setting up defense systems, such as pallisades. This stark geography imposed by the European traders "was a minimal construction of nodes and circuits intended to facilitate trade in an isolated corner of the world, and to make connections to distant managers and markets." ${ }^{x l v}$ 
Aboriginal communities remained self-governing in these fur trade landscapes and it was company men at isolated posts who depended on their Indian neighbors and exchange partners for meat, fish, produce, gum for their canoes, guidance and protection. European and Euroamerican traders also established unions of different lengths with Native women, giving rise to a mixed race population within the fur trade that further complicated the pulls of localized interests shaping an area. The immediate and contingent politics of community that determine how people inhabit places was, in the open-ended sphere of trading posts and Indian villages, a many-headed phenomenon. As Jennifer S. H. Brown has elaborated, "the trade was built upon and spawned a broad spectrum of Aboriginal, mixed, and newcomer communities that related with one another in diverse, complex ways that changed over time." ${ }^{\text {xlvi }}$ Moreover, these multiple, interacting communities were mobile and seasonal. Trading posts, often distant from each other, represented points of conflict, exchange and social activity within otherwise decentralized and centrifugal trading worlds. It was here at the local level that the diverse peoples of the fur trade chose whether and how to accommodate to changing imperial, national, and company boundaries. The fluid and varied notions of space and place allowed those in the fur trade to configure ideas about race in novel and unexpected ways. One of the most unusual expressions of this fluidity was freemen who, on leaving the fur trade service, remained in fur trade territory without joining Aboriginal communities. These men lived either independently or in small mobile communities of like-minded souls, eking a living from a variety of economic strategies that could include trapping, trading, hunting, fishing, gathering, farming, and small-scale manufacturing of pemmican, canoes, moccasins and other necessities of fur trade life. Undoubtedly some 
freemen and their Native wives became the proto-generation of métis, but others developed distinct communities, places and ways of using space that did not make their way into the historical record and did not survive the exigencies of time.

\section{The Limits of National Histories}

Although the shadow of the nation-state frames a great deal of American and Canadian fur trade historiographies over the past century, the subject itself defies easy compartmentalization to a single dynamic like national or imperial politics. The North American fur trade is an umbrella term referring to a myriad of historically and geographically specific, localized exchange economies, which brought together Europeans, Euroamericans and Aboriginal peoples and fostered dynamic social, economic and political relationships among them. Additionally, the fur trade operated along many spatial levels often simultaneously-- global, hemispheric, national, regional, central trading towns, rendezvous sites, local company posts and Indian camps. Because the fur trade encompassed such a wide spectrum of geographic spheres, and it involved culturally and politically diverse peoples with alternative identities to national ones, it stands as a critique of the limitations of national histories. The North American fur trade illustrates the nuanced and multiple ways that people inhabited and formed their histories in spaces not exclusively and sometimes not at all shaped by the dynamics of the nationstate.

Nations tend to create centripetal forces in their societies, drawing people together into a common identity. National identities express the fictive kinship of people in the interior of a state, not at the edges, and state borders reinforce the distinctiveness of that 
interior from its neighbors. The fur trade operated along multiple, layers of interconnected spaces that included national boundaries but also expanded into international capitalist networks and transnational trading companies and narrowed to culturally counter-national spaces at the regional and local levels. Thus, pre-existing physical and Aboriginal geographies, commercial interests, local dynamics surrounding fur trade posts and new kin ties all pulled against nationalist forces. Indeed, the North American fur trade fostered open-ended cultural constructions as European, Euroamerican, mixed race and Native people accommodated, adopted, created and resisted cultural change to varying degrees and formed a diverse range of communities and associations.

Nonetheless, the diverging paths of historiography of the fur trade on either side of the Canada - United States border clearly show how nationalist consciousnesses has circumscribed historical interpretation despite innovative ethnohistorical approaches and a much better sense of the reflexive, progressive teleology of nation-state centered histories. This article seeks to remind historians that history need not be teleological. Territoriality and situated identities in North America must be studied as though the creation of the American and Canadian nations and the border between them did not exist, that is, right up until the point when they did come into being. Even after that point, a wide variety of dynamics beyond governmental assertions constructed the historically contingent and multiple understandings of borders among culturally and politically diverse populations in both Canada and the United States. It is time to shatter the glass curtain. 


\section{Bibliography}

Acland, Charles R. \& William J. Buxton, eds. Harold Innis in the New Century. Montreal \& Kingston: McGill-Queen's University Press, 1999.

Albers, Patricia and Jeanne Kay, "Sharing the Land: A Study in American Indian Territoriality," in A Cultural Geography of North American Indians, ed. Thomas E. Ross \& Tyrel G. Moore, 47-91.

Allaire, Gratien. "Les engagements pour la traite des fourrures: évaluation de la documentation." Revue d'histoire de l'amérique française 34 (June 1980), 3-26.

Allaire, Gratien. "Fur Trade Engages, 1701-1745." In Rendezvous: Selected Papers of the Fourth North American Fur Trade Conference. Edited by Thomas C. Buckley. St. Paul, MN: The Conference, 1984.

Bailyn, Bernard. “The Idea of Atlantic History,” Itinerario 20 (1996): 19-44.

Barkwell, Lawrence J., Leah Dorion, and Darren Préfontaine, eds. Metis Legacy: A Metis Historiography and Annotated Bibliography. Winnipeg: Pemmican Publications, 2001.

Binnema, Theodore. Common and Contested Ground: A Human and Environmental History of the Northwestern Plains. Tulsa: University of Oklahoma Press 2001 and Toronto: University of Toronto Press, 2004.

Bolus, Malvina, ed. People and Pelts: Selected Papers of the Second North American Fur Trade Conference. Winnipeg: Peguis Publishers, 1972.

Braund, Kathryn E. Holland. Deerskins and Duffels: The Creek Indian Trade with AngloAmerica, 1685-1815. Lincoln: University of Nebraska Press, 1993.

Brown, Jennifer S. H. Strangers in Blood: Fur Trade Company Families in Indian Country. Vancouver: University of British Columbia Press, 1980.

Brown, Jennifer S. H. "The Blind Men and the Elephant: Fur Trade History Revisited. In Patricia A. McCormack and R. Geoffrey Ironsides, eds., The Uncovered Past: Roots of Northern Alberta Societies. Edmonton: Canadian Circumpolar Institute, University of Alberta, 1993.

Brown, Jennifer S. H. "Fur Trade as Centrifuge: Familial Dispersal and Offspring Identity in Two Company Contexts." In Raymond J. DeMallie and Alfonso Ortiz, eds., 
North American Indian Anthropology: Essays on Society and Culture, 197-219. Norman: University of Oklahoma Press, 1994.

Brown, Jennifer S. H. "Partial Truths: A Closer Look at Fur trade Marriage." In Theodore Binnema, Gerhard J. Ens, and R. C. Macleod, eds., From Rupert's Land to Canada, 5980. Edmonton: University of Alberta Press, 2001.

Brown, Jennifer S. H. "Names and Metaphors in Metis Historiography: Old Categories and nouvelles eclaircies." Recherches Amerindiennes au Quebec, 2008 (in press).

Brown, Jennifer S. H. and Elizabeth Vibert, eds. Reading Beyond Words: Contexts for Native History. Peterborough: Broadview, 1996, $2^{\text {nd }}$ edition, 2003.

Brown, Jennifer S. H., W. J. Eccles, and Donald P. Heldman, eds. The Fur Trade Revisited: Selected papers of the Sixth North American Fur Trade Conference, Mackinac Island, Michigan, 1991. East Lansing and Mackinac Island: Michigan State University Press and Mackinac State Historic Parks, 1994.

Buckley, Thomas C. Rendezvous: Selected Papers of the Fourth North American Fur Trade Conference, 1981. St. Paul: North American Fur Trade Conference, 1984.

Bumsted, J. M. "The Quest for a Usable Founder: Lord Selkirk and Manitoba Historians, 1856-1923," Manitoba History 2 (1981): pgs?

Burley, Edith I. Servants of the Honourable Company: Work, Discipline, and Conflict in the Hudson's Bay Company, 1770-1879. Toronto, New York and Oxford: Oxford University Press, 1997.

Calloway, Colin. One Vast Winter Count: The Native American West Before Lewis and Clark. Lincoln, NE: the University of Nebraska, 2003.

Calloway, Colin. "Neither White Nor Red: White Renegades on the American Indian Frontier," The Western Historical Quarterly, 17, 1 (January 1986): pp. 43-66.

Campbell, Marjorie Wilkins. The Nor'westers: The Fight for the Fur Trade. Toronto: Macmillan, 1954

Campbell, Marjorie Wilkins. The North West Company. Toronto: Macmillan, 1957.

Campbell, Marjorie Wilkins. McGillivray, Lord of the Northwest. Vancouver: Clark, Irwin, 1962.

Careless, J. M. S. Canada: A Story of Challenge. 1953.

Cleland, Robert Glass. This Reckless Breed of Men: The Trappers and Fur Traders of the Southwest. New York: Knopf, 1950. 
Clifford, James. Routes: Travel and Translation in the Late Twentieth Century.

Cambridge: Harvard university Press, 1997.

Cline, Gloria Griffen. Exploring the Great Basin. Norman: University of Oklahoma Press, 1963.

Creighton, Donald. The Empire of the St. Lawrence: A Study in Commerce and Politics, 1760-1850. Toronto: Ryerson Press, 1937.

Cronon, William. Changes in the Land: Indians, Colonists, and the Ecology of New

England. New York: Hill and Wang, 1983.

Dechêne, Louise. Habitants and Merchants in Seventeenth-Century Montreal. Montreal and Kingston: McGill-Queen's University Press, 1992. First published as Habitants et marchands de Montréal au XVIIe siècle. Paris: Editions Plon, 1974.

Devine, Heather. The People Who Own Themselves: Aboriginal Ethnogenesis in a Canadian Family 1660-1900. Calgary: University of Calgary Press, 2004.

Dillon, Richard H. Siskiyou Trail: The Hudson's Bay Company Route to California. New York: McGraw-Hill, 1975.

Duara, Prasenjit. Rescuing History from the Nation: Questioning Narratives of Modern China. Chicago: University of Chicago Press, 1995.

Eccles, W. J. "The Fur Trade and Eighteenth-Century Imperialism." William and Mary Quarterly 3rd series, XL: 3 (July 1983), 341-62.

Fisher, Robin. Contact and Conflict: Indian-European Relations in British Columbia, 1774-1890. Vancouver: University of British Columbia Press, 1977.

Fiske, Jo-Anne, Susan Sleeper-Smith, and William Wicken, eds. New Faces in the Fur Trade: Select Papers of the Seventh North American Fur trade Conference, Halifax, Nova

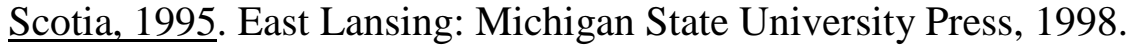

Foster, John Elgin. "The Country-born in the Red River Settlement, 1820-1850." Ph.D. dissertation, University of Alberta, 1973.

Francis, Daniel and Toby Mortanz. Partners in Furs: A History of the Fur Trade in Eastern James Bay 1600-1870. Montreal: McGill-Queen's University Press, 1983.

Gibson, James R. Otter Skins, Boston Ships, and China Goods: The Maritime Fur Trade of the Northwest Coast, 1785-1841. Seattle : University of Washington Press, 1992. 
Giraud, Marcel. Les Métis canadien: son rôle dans l'histoire des provinces de l'Ouest. Paris : Institut d'ethnologie, 1945. English translation published as The Métis in the Canadian West. Translated by George Woodcock. Edmonton: University of Alberta Press, 1985.

Golay, Michael. The Tide of Empire: America's March to the Pacific. Hoboken, NJ: Wiley, 2003.

Goulet, Keith. "The Cumberland Cree Nehinuw Concept of Land." Presented at the Indigenous Knowledge Systems: International Symposium, University of Saskatchewan, Saskatoon, 2004.

Grabowski, Jan and Nicole St-Onge. "Montreal Iroquois Engagés in the Western Fur Trade, 1800-1821." From Rupert's Land to Canada: Essays in Honour of John E. Foster. Edited by Theodore Binnema, Gerhard J. Ens and R. C. MacLeod, 23-58. Edmonton: University of Alberta Press, 2001.

Greenbie, Sydney. Furs to Furrows: An Epic of Rugged Individualism. Caldwell, Id.: Caxton Printers, 1939.

Greer, Allan. "Fur-Trade Labour and Lower Canadian Agrarian Structures." In Canadian Historical Association Historical Papers 1981, 197-214.

Greer, Allan and Jodi Bilinkoff, eds. Colonial Saints: Discovering the Holy in the Americas. New York: Routledge, 2003.

Hale, Nathaniel C. Pelts and Palisades: The Story of Fur and the Rivalry for Pelts in Early America. Richmond, Va.: The Dietz Press, 1959.

Harris, Cole. The Resettlement of British Columbia: Essays on Colonialism and Geographical Change. Vancouver: University of British Columbia Press, 1997.

Innis, Harold A. The Fur Trade in Canada: An Introduction to Canadian Economic History. New Haven: Yale University Press, 1930. Rev. Ed., Toronto: University of Toronto Press, 1956.

Irving, Washington. The Adventures of Captain Bonneville, or, Scenes beyond the Rocky Mountains of the Far West. London: R. Bentley, 1837.

Irving, Washington. Astoria , or, Enterprise beyond the Rocky Mountains. London: R. Bentley, 1836.

Irving, Washington. A Tour of the Prairies. Philadelphia: Carey, Lea, \& Blanchard, 1835.

Irving, Washington. Three Western Narratives: A Tour of the Prairies, Astoria, The Adventures of Captain Bonneville. New York: The Library of America, 2004. 
Jackson, John C. Children of the Fur Trade: Forgotten Métis of the Pacific Northwest. Missoula: Mountain Press Pub. Co., 1995.

Johnson, Louise, ed. Aboriginal People and the Fur trade: Proceedings of the $8^{\text {th }}$ North America Fur Trade Conference. Akwesasne. Cornwall, ON and Rooseveltown, NY: Akwesasne Notes Publishing, 2001.

Judd, Carol M. "Native Labour and Social Stratification in the Hudson's Bay Company's Northern Department, 1770-1870." Canadian Review of Sociology and Anthropology 17: 4 (November 1980), 305-14.

Judd, Carol M. and Arthur J. Ray, eds. Old Trails and new Directions: Papers of the Third North American Fur trade Conference. Toronto: University of Toronto Press, 1980.

Karamanski, Theodore J. "The Iroquois and the Fur Trade of the Far West." The Beaver (Spring 1982), 5-13.

Lamar, Howard R. The Trader on the American Frontier: Myth's Victim. College Station: Texas A \& M University Press, 1977.

Lavender, David. A Fist In the Wilderness. Albuquerque: University of New Mexico Press, 1964.

Lewis, Oscar. The Effects of White Contact Upon Blackfoot Culture, With Special Reference to the Role of the Fur Trade. New York, J. J. Augustin, 1942.

Lloyd, David. "Nationalisms Against the State." In Lisa Lowe and David Lloyd, eds., The Politics of Culture in the Shadow of Capital, 173-98. Durham: Duke University Press, 1997.

Lytwyn, Victor P. The Fur Trade of the Little North: Indians, Peddlars, and Englishmen East of Lake Winnipeg, 1760-1821. Winnipeg: Rupert's Land Research Centre, 1986.

Mancke, Elizabeth. "Spaces of Power in the Early Modern Northeast." In Stephen J. Hornsby and John G. Reid, eds., New England and the Maritime Provinces: Connections and Comparisons, 32-49. Montreal: McGill-Queen's University Press, 2005.

Mann, Michael. The Sources of Power, vol. 1, A History of Power from the Beginning to A.D. 1769. Cambridge: Cambridge University Press, 1986.

Martin, Calvin. Keepers of the Game: Indian-Animal Relationships and the Fur Trade. Berkeley: University of California Press, 1978. 
McCoy, Drew R. The Elusive Republic: Political Economy in Jeffersonian America. Chapel Hill: Institute of Early American History and Culture, University of North Carolina Press, 1980.

Merchant, Carolyn. Ecological Revolutions: Nature, Gender and Science in New England. Chapel Hill, NC: University of North Carolina Press, 1989.

Merrell, James H. The Indians' New World: Catawbas and their Neighbors from European Contact Through the Era of Removal. Chapel Hill: Institute of Early American History and Culture, University of North Carolina Press, 1989.

Merwick, Donna. Possessing Albany, 1630-1710. New York and Cambridge, UK: Cambridge University Press, 1990.

Mitchell, Elaine Allen. Fort Timiskaming and the Fur Trade. Toronto: University of Toronto Press, 1977.

Morgan, Dale L., W. L. Morton, K. G. Davies et. al. Aspects of the Fur Trade: Selected Papers of the 1665 North American Fur Trade Conference. St. Paul: Minnesota Historical Society, 1967.

Morton, W. L. Manitoba: A History. Toronto: University of Toronto Press, 1957.

Murphy, Lucy Eldersveld. A Gathering of Rivers: Indians, Métis, and Mining in the Western Great Lakes, 1737-1832. Lincoln: University of Nebraska Press, 2000.

Nicks, John. "Orkneymen in the HBC, 1780-1821.” In Old Trails and New Directions: Papers of the Third North American Fur Trade Conference. Edited by Carol M. Judd and Arthur J. Ray, 102-26. Toronto: University of Toronto Press, 1980.

Nicks, Trudy. "The Iroquois and Fur Trade in Western Canada." In Old Trails and New Directions: Papers of the Third North American Fur Trade Conference. Edited by Carol M. Judd and Arthur J. Ray. Toronto: University of Toronto Press, 1980.

Norton, Thomas Elliot. The Fur Trade in Colonial New York. Wisconsin: University of Wisconsin Press, 1974.

O'Meara, Walter. Daughters of the Country: The Women of the Fur Traders and Mountain Men. New York: Harcourt, Brace \& World, 1968.

Pannekoek, Fritz. "The Churches and the Social Structure in the Red River Area, 181870.” Ph.D. dissertation, Queen's University, 1973.

Pannekoek, Fritz. A Snug Little Flock: The Social Origins of the Riel Resistance of 18691870. Winnipeg: Watson \& Dwyer Publishing, 1991. 
Pannekoek, Fritz. "Metis Studies: The Development of a Field and new Directions." In Theodore Binnema, Gerhard J. Ens, and R. C. Macleod, eds., From Rupert's Land to Canada, 111-28. Edmonton: University of Alberta Press, 2001.

Parker, James. Emporium of the North: Fort Chipewyan and the Fur Trade to 1835. Regina: Canadian Plains Research Centre and Alberta Culture and Multiculturalism, 1987.

Payment, Diane. "The Free People - Otipemisiwak" Batoche, Saskatchewan 1870-1930. Ottawa: National Historic Parks and Sites, 1990.

Payne, Michael. "Fur Trade Social History and the Public Historian: Some Other Recent Trends.” In Jennifer S. H. Brown, W. J. Eccles, and Donald P. Heldman, eds., The Fur Trade Revisited: Selected papers of the Sixth North American Fur Trade Conference, Mackinac Island, Michigan, 1991, 481-99. East Lansing: Michigan State University Press, 1994.

Payne, Michael. "Fur Trade Historiography: Past Conditions, Present Circumstances and a Hint of Future Prospects." In Theodore Binnema, Gerhard J. Ens, and R. C. Macleod, eds., From Rupert's Land to Canada, 3-22. Edmonton: University of Alberta Press, 2001.

Peers, Laura and Robert Coutts. "Aboriginal History and Historic Sites: The Shifting Ground.” In Laura Peers and Carolyn Podruchny, eds. Gathering Places: Essays on Aboriginal Histories in Honour of Jennifer S. H. Brown. Paper in circulation.

Peterson, Jacqueline. "The People In Between: Indian-White Marriage and the Genesis of a Métis Society and Culture in the Great Lakes Region, 1680-1830.” Ph.D. Thesis. Chicago: University of Illinois at Chicago Circle, 1980.

Peterson, Jacqueline and John Afinison. "The Indian and the Fur Trade: A Review of Recent Literature.” In W. R. Swagerty, ed., Scholars and the Indian Experience: Critical Reviews of Recent Writing in the Social Sciences, 223-57. Bloomington: Indiana University Press, 1984. Later published in revised form in Manitoba History 10 (Autumn 1985), 10-18.

Peterson, Jacqueline and Jennifer S. H. Brown, eds. The New Peoples: Being and Becoming Métis in North America. Winnipeg: University of Manitoba Press, 1985.

Phillips, Paul C. (with concluding chapters by J.W. Smurr). The Fur Trade, 2 vols. Norman: University of Oklahoma Press, 1961.

Podruchny, Carolyn. Making the Voyageur World: Traders and Traders in the North American Fur Trade. Lincoln: University of Nebraska Press and Toronto: University of Toronto Press, 2006. 
Pope, Peter. "The Practice of Portage in the Early Modern North Atlantic: Introduction to an Issue in Maritime Historical Anthropology." Journal of the Canadian Historical Association. 1995 (new series) 6, 19-41.

Ray, Arthur J. Indians in the Fur Trade: Their Roles as Hunters, Trappers and Middlemen in the Lands Southwest of Hudson Bay, 1660-1870. Toronto: University of Toronto Press, 1974.

Ray, Arthur J. Ray and Donald Freeman. 'Give Us Good Measure': An Economic Analysis of Relations Between the Indians and the Hudson's Bay Company Before 1763. Toronto: University of Toronto Press, 1978.

Rich, E. E. The Fur Trade and the Northwest to 1857. Toronto: McClelland and Stewart Limited, 1967.

Ronda, James. Astoria and Empire. Lincoln: University of Nebraska Press, 1990.

Ross, Alexander. Adventures of the First Settlers on the Oregon or Columbia River; being a narrative of the expedition fitted out by John Jacob Astor to establish the "Pacific Fur Company;" with an account of some of the Indian Tribes on the coast of the Pacific. London: Smith, Elder and Co., 1849; Chicago: R.R. Donnelley, 1923; Lincoln, Nebraska: University of Nebraska Press, 1986; Oregon State University Press, 2000.

Ross, Alexander. The Fur Hunters of the Far West; a narrative of adventures in the Oregon and Rocky Mountains, 2 vols. London: Smith, Elder \& Co., 1855; Chicago: Lakeside Press, R.R. Donnelly \& Sons Company, 1924; Norman: University of Oklahoma Press, 1956.

Ross, Alexander. Red River Settlement; its rise, process and present state. With some account of the native races and its general history, to the present day. London: Smith, Elder \& Co., 1856.

Rudin, Ronald. Making History in Twentieth-Century Quebec. Toronto: University of Toronto Press, 1997.

Skinner, Clairborne. "The Sinews of Empire: The Voyageurs and the Carrying Trade of the Pays d'en Haut, 1681-1754." Ph.D. thesis. Chicago: University of Illinois at Chicago, 1991.

Sleeper-Smith, Susan. Indian Women and French Men: Rethinking Cultural Encounter in the Western Great Lakes. Amherst: University of Massachusetts Press, 2001.

Slotkin, Richard. Regeneration Through Violence: The Mythology of the American Frontier. Middleton, CT: Wesleyan University Press, 1973. 
Stanley, George F. G. The Birth of Western Canada: A History of the Riel Rebellions. Toronto: University of Toronto Press, 1961.

St.-Onge, Nicole. Saint-Laurent, Manitoba: Evolving Métis Identities, 1850-1914.

Regina: Canadian Plains Research Centre, University of Regina, 2004.

Strathern, Marilyn. The Gender of the Gift: Problems with Women and Problems with Society in Melanesia. Berkeley: University of California Press, 1988.

Swagerty, William R. and Dick A. Wilson, "Faithful Service under Different Flags: A Socioeconomic Profile of the Columbia District, Hudson's Bay Company and the Upper Missouri Outfit, American Fur Company, 1825-1835." In The Fur Trade Revisited; Selected Papers of the Sixth North American Fur Trade Conference, Mackinac Island, Michigan, 1991. Edited by Jennifer S. H. Brown, W. J. Eccles, and Donald P. Heldman, 243-67. East Lansing, Michigan: Michigan State University Press, 1994.

Tanner, Adrian. “The End of Fur Trade History.” Queen's Quarterly 90: 1 (Spring 1983).

Tanner, Helen Hornbeck, ed. The Settling of North America: The Atlas of the Great Migrations into North America from the Ice Age to the Present. New York: Macmillan Press, 1995.

Thistle, Paul C. Indian-European Trade Relations in the Lower Saskatchewan River Region to 1840. Winnipeg: University of Manitoba Press, 1986.

Thomas, L. G. "Historiography of the Fur Trade Era." In Richard Allen, ed. A Region of the Mind, 73-85. Regina: Canadian Plains Research Centre, 1973.

Thorne, Tanis C. The Many Hands of My Relations: French and Indians on the Lower Missouri. Columbia: University of Missouri Press, 1996.

Trigger, Bruce G., Toby Morantz, and Louise Dechene, eds. "Le Castor Fait Tout": Selected Papers of the Fifth North American Fur Trade Conference, 1985. Montreal: Lake St. Louis Historical Society, 1987.

Turgeon, Laurier. "Le temps des pêches lointaines: permanences et transformations (vers 1500 - vers 1850)." In Histoire des pêches maritimes en France, edited by M. Mollat, 134-81. Toulouse: 1987.

Turner, Frederick Jackson. The Character and Influence of the Indian Trade in Wisconsin: A Study of the Trading Post as an Institution. Baltimore: Johns Hopkins Press, 1891.

Turner, Frederick Jackson. "The Character and Influence of the Indian Trade in Wisconsin: A Study of the Trading Post as an Institution." In Herbert B. Adams, ed., 
Johns Hopkins University Studies in Historical and Political Science, $19^{\text {th }}$ Ser., xi-xiii (Nov.-Dec. 1891).

Turner, Frederick Jackson. "The Significance of the Frontier in American History."

Presented at the American Historical Association Annual Meeting in Chicago in 1893. Printed in the Proceedings of the State Historical Society of Wisconsin, December 14, 1893. Reprinted in John Mack Faragher, ed. Rereading Frederick Jackson Turner. New Haven, CT: Yale University Press, 1998.

Usner, Daniel H. Indians, Settlers and Slaves in a Frontier Exchange Economy: The Lower Mississippi Valley before 1783. Chapel Hill: Institute of Early American History and Culture, University of North Carolina Press, 1992.

Utley, Robert. A Life Wild and Perilous: Mountain Men and the Paths to the Pacific. New York: Henry Holt and Co., 1997.

Van Kirk, Sylvia. 'Many Tender Ties': Women in Fur-Trade Society, 1670-1870. Winnipeg: Watson \& Dwyer Publishing Ltd., 1980.

Vibert, Elizabeth. Traders' Tales: Narratives of Cultural Encounters in the Columbia Plateau, 1807-1846. Norman and London: University of Oklahoma Press, 1997.

Weber, David J. The Taos Trappers: The Fur Trade in the Far Southwest, 1540-1846. Norman, OK: University of Oklahoma Press, 1969.

White, Bruce M. "A Skilled Game of Exchange: Ojibwa Fur Trade Protocol." Minnesota History 50: 6 (summer 1987): 229-40.

White, Bruce M. "The Fear of Pillaging: Economic Folktales of the Great Lakes Fur Trade." In The Fur Trade Revisited: Selected Papers of the Sixth North American Fur Trade Conference, Mackinac Island, Michigan, 1991. Edited by Jennifer S.H. Brown, W.J. Eccles, and Donald P. Heldman, 199-216. East Lansing, MI: Michigan State University Press, 1994.

White, Richard. The Roots of Dependency: Subsistence, Environment, and Social Change Among the Choctaws, Pawnees, and Navajos. Lincoln: University of Nebraska Press, 1983.

White, Richard. The Middle Ground: Indians, Empires, and Republics in the Great Lakes Region. Cambridge: Cambridge University Press, 1991.

'See Turgeon "Le temps des pêches lointaines" and Pope, "The Practice of Portage in the Early Modern North Atlantic." 
ii The strongest counter to nationalist biases in fur trade historiography constitutes the published proceedings of the first eight North American Fur Trade Conferences. See Morgan, Morton and Davies, eds., Aspects of the Fur Trade (1967); Bolus, ed., People and Pelts (1972); Judd and Ray, eds., Old Trails and New Directions (1980); Buckley, ed., Rendezvous (1984); Trigger, Morantz, and Dechene, eds., Le Castor Fait Tout (1987); Brown, Eccles, and Heldman, eds., The Fur Trade Revisited (1994); Fiske, Sleeper-Smith, and Wicken, eds., New Faces of the Fur Trade; and Johnson, ed., Aboriginal People and the Fur Trade (2001). Rhoda and Carolyn Gilman provided a superb recounting of these conferences and description of these proceedings in a keynote address at the Ninth North American Fur Trade Conference in St. Louis in May 2006.

iii Calloway, One Vast Winter Count, 7-17.

${ }^{\text {iv }}$ See McCoy, The Elusive Republic for a discussion of this romantic view of the yeoman farmer.

${ }^{v}$ Irving, Three Western Narratives, 629.

${ }^{v i}$ Irving explained in his introduction to The Adventures of Captain Bonneville, that Bonneville had attempted to write up his memoirs and produced a "mass of manuscript, which he subsequently put at my [Irving's] disposal, to fit it for publication and bring it before the world." Irving, Three Western Narratives, 632.

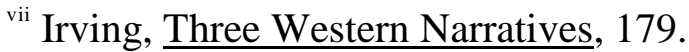

viii Irving, Three Western Narratives, 180, 183.

ix Turner, "The Character and Influence of the Indian Trade in Wisconsin" in Adams, ed., Johns Hopkins University Studies, 558.

${ }^{x}$ In Regeneration Through Violence, Richard Slotkin makes the distinction between Euroamericans who adopted Native customs, dress, language etc. and lived among Indian peoples and Native people themselves. Characters like Daniel Boone could and did return to "civilized" life after a time. At the same time, in his article "Neither White Nor Red," 43, Colin Calloway has explored how the nineteenth-century U.S. literary descriptor of "renegade" referred "someone who abandoned white society to live with Indians." In both cases, a subtle distinction is implied between Euroamerican and Indian "savagery."

${ }^{x i}$ Clifford, Routes, 329. Nearly thirty years ago, western historian Howard R. Lamar challenged American historians to stop letting national myths direct their interpretation of the fur trade. More specifically, he argued that traders and trappers "myth's victim," maintaining that frontier historians "have neglected a dual tradition of trade and mercantile capitalism by overstressing the mythic figures of explorers, pioneers and settlers." Lamar cogently attacked the impression of the temporariness and recession of the fur trade by showing the extremely long history of North American exchange economies stretching back to a prehistoric trade among Indian peoples and encompassing an Indian-European-descent trading world from 1600 to 1850. Moreover, far from disappearing by 1850, Euroamerican traders and trappers merely diversified into any range of capitalist endeavors such as merchandisers or hostelers when animal supplies 
dwindled and federal authorities segregated their Indian partners on reservations. See Lamar, The Trader on the American Frontier, quote on 17.

${ }^{x i i}$ Greenbie, Furs to Furrows, 2.

xiii Cleland, This Reckless Breed of Men, 5.

${ }^{\text {xiv }}$ O'Meara, Daughters of the Country, 8.

"Tv To offer a few more examples of this pervasive interpretation of fur traders as "pathfinders and precursors," historian Nathaniel Hale succinctly captured the distinctive value of the fur trade in the progress of European-descent settlement of North America by arguing that "[i]t sustained the colonies along the Atlantic seaboard until they could be rooted in agriculture, and it was a controlling factor in the westward movement of our population." Hale, Pelts and Palisades, vii. More recently, Michael Golay collapses prior distinctions between self-interested fur traders and those early adventurers/ pathbreakers presuming more selfless aims and celebrates "the transformational power of American energy" in the push wrought by individual traders, missionaries and explorers for an American empire in the Pacific Northwest, see Golay, The Tide of Empire, xiii.

${ }^{x v i}$ Duara, Rescuing History from the Nation, 27.

${ }^{\text {xvii }}$ Likewise, Quebec historians portraying New France as the golden age of French Canadian independence pair agriculture and the fur trade as twin economic pillars to the success of the colony, but debate the relative importance of each. The influence of Quebec nationalism on fur trade historiography, and more broadly on the writing of Quebec history, has a long and complex history and is outside the parameters of this essay. The rupture of the Conquest, and the replacement of one colonial regime with another, created distinct patterns in the imagining of a national history, and the place of the fur trade within it, that deserve a detailed study not possible in the confines of this article. For recent work on nationalism and historiography in Quebec, see Rudin, Making History in Twentieth-Century Quebec and the debate in the Canadian Historical Review "Forum" in 80: 4 (December 1999), 641-86.

xviii Dictionary of Canadian Biography Online, entry on Alexander Ross written by Fritz Pannekoek.

${ }^{x i x}$ For a detailed examination of the historiography of Manitoba history, see Bumsted, "The Quest for a Usable Founder."

${ }^{\mathrm{xx}}$ Innis, The Fur Trade in Canada, 393.

${ }^{\mathrm{xxi}}$ Innis has been the focus for much historiographical and cultural commentary, most recently in the 1999 Acland and Buxton, eds., Harold Innis in the New Century.

xxii Thomas, "Historiography of the Fur Trade Era." Also see Payne, "Fur Trade Historiography."

xxiii See Judd, "Native Labour and Social Stratification in the Hudson's Bay Company's Northern Department;" Swagerty and Wilson, "Faithful Service under Different Flags;" J. Nicks, "Orkneymen in the HBC;" Skinner, "The Sinews of Empire;" Burley, Servants of the Honourable Company; Podruchny, Making the Voyageur World; Allaire, "Les 
engagements pour la traite des fourrures;" Allaire, "Fur Trade Engages;" Dechêne, Habitants and Merchants, 117-24; Greer, "Fur-Trade Labour and Lower Canadian Agrarian Structures ;" Grabowski and St.-Onge, "Montreal Iroquois Engagés;” T. Nicks, "The Iroquois and Fur Trade in Western Canada;" and Karamanski, "The Iroquois and the Fur Trade."

${ }^{\text {xxiv }}$ See Fisher, Contact and Conflict; Francis and Mortantz, Partners in Furs; and Thistle, Indian-European Trade Relations. For historiographical articles exploring the work on Indians in the fur trade see for other historiographical articles see Tanner, "The End of Fur Trade History" and Peterson and Anfinison, "The Indian in the Fur Trade."

${ }^{x x v}$ For a few examples see Merrell, The Indians' New World; Usner, Indians, Settlers, and Slaves; Norton, The Fur Trade in Colonial New York; Merchant, Ecological $\underline{\text { Revolutions; }}$; and Merwick, Possessing Albany.

${ }^{x x v i}$ For bibliographies on much of this literature, see Barkwell, Dorion, and Préfontaine, eds., Metis Legacy, 273-505 and Pannekoek, "Métis Studies."

xxvii Thorne, The Many Hands of My Relations, 9.

xxviii Payne, "Fur Trade Social History," 482.

${ }^{\text {xxix }}$ For their mandate, see http://www.pc.gc.ca/agen/index_E.asp.

${ }^{\mathrm{xx}}$ For further discussion of counter-national identities see Clifford, "Fort Ross Meditation," in Routes; and Lloyd, "Nationalisms Against the State," 173-198.

xxxi Trends in Métis historiography are outlined in Pannekoek, "Metis Studies."

xxxii This tradition has been carried on by Lytwyn, The Fur Trade of the Little North and Harris, The Resettlement of British Columbia.

xxxiii Peterson with Afinson, "The Indian and the Fur Trade," 1.

${ }^{\text {xxxiv }}$ Tanner, ed., The Settling of North America, 28-29.

${ }^{x x x v}$ Albers and Kay, "Sharing the Land."

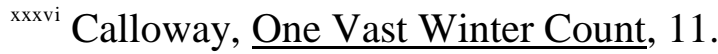

xxxvii Goulet, "The Cumberland Cree Nehinuw Concept of Land."

xxxviii For example, Keith Goulet is writing his doctoral dissertation at the University of Regina on Cree Nehinuw concepts of land, exploring how animate and inanimate objects shaped the way people viewed land. The idea of "root epistemologies" of cultures originates from Marilyn Strathern, The Gender of the Gift.

${ }^{\text {xxxix } \text { Basso, Wisdom Sits in Places, }}$ xv.

${ }^{\mathrm{xl}}$ Albers and Kay, "Sharing the Land."

xli For a similar way of conceptualizing landscape as "spaces of power" see Mann, The

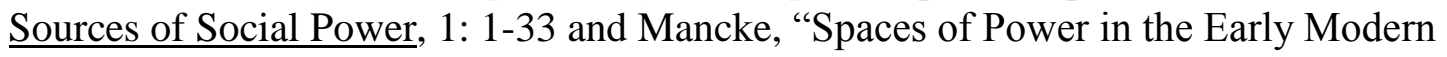
Northeast." 
xlii See for example Eccles, "The Fur Trade and Eighteenth-Century Imperialism" and Bailyn, "The Idea of Atlantic History."

xliii A good example of a hemispheric approach to colonial history is Greer and Bilinkoff, eds., Colonial Saints.

xliv For a couple of examples of studies of individual posts, see Parker, Emporium of the North, and Mitchell, Fort Timiskaming and the Fur Trade.

${ }^{\text {xlv }}$ Harris, The Resettlement of British Columbia, 32-42, quotes on 34, 42.

xlvi Brown, "Names and Metaphors." 